\title{
Perceptions of the Usage of WhatsApp for Instruction: A Study of Teachers in Senior High Schools in Ghana
}

\author{
Frederick Owusu-Boakye; Abednego Kofi Bansah; Justice Armah \\ University of Cape Coast, Central Region, Ghana
}

\begin{abstract}
The free education policy at the senior high school levels in Ghana resulted in an increase in enrollment numbers which subsequently lead to the adoption of the double track system which necessitated the need to divide students into two tracks. This meant that while one track was in school, the other was on vacation. As such, an innovative way is needed to keep students' engage especially a track that is on vacation. The purpose of this research was to determine the perception of teachers on the usage of WhatsApp messenger for teaching and learning. A cross-sectional design was employed in this study among 125 senior high school teachers within Tema Metropolis of Ghana. The research revealed that, perceived cost had an effect on teachers perceive usefulness, perceived convenience, perceived effectiveness, perceived trust and perceived intension to use WhatsApp Messenger for teaching and learning. Perceived convenience had a more pronounced effect on perceived usefulness. Implications of the results for scaling up or developing reforms on regular stakeholder's consultations to understand the concept of using WhatsApp messenger for teaching and learning in high schools with similar context are discussed.
\end{abstract}

Keywords: WhatsApp; Instruction; Perceived Usefulness; Perceived Convenience; Intention to Use

\section{INTRODUCTION}

$\mathrm{F}$ or the past decade, the world continues to encounter correspondence insurgency through technological headway and the education sector is no exception to this insurgence. Tools such as WhatsApp, Twitter, LinkedIn Learning, and YouTube continue to impact teaching and learning. This has compelled teachers to re-think their instructional methods to enhance the way students learn (Mynbayeva \& Sadvakassova, 2018). The $21^{\text {st }}$ century teacher is able to connect with students utilizing any accessible online networking channels at their very own pace (Mynbayeva \& Sadvakassova, 2018). One important social networking tool that has received significant usage in the learning environment is the WhatsApp Messenger (Devi et al., 2019; Jadhav et al., 2013). The integration of WhatsApp in teaching can greatly enhance the quality of learning (Susilo, 2014) and has been viewed as a compelling correspondence and communityoriented tool for teaching and learning due to its favourable circumstances over different types of online networking devices (Willemse 2015). WhatsApp is viewed as a tool that can encourage critical discussion, information sharing among students and teachers, improve students' manipulative abilities, encourage the learning procedure and cultivate assessment process (Barhoumi, 2015; Lauricella \& Kay, 2013). It also helps students build their very own insight (Namaziandost \& Nasri, 2019), improve correspondence, imagination, basic reasoning and critical thinking aptitudes (Namaziandost \& Nasri, 2019; Willemse 2015) as well as information handling skills and problem-solving capacity (Willemse, 2015).

Policies related to education continue to revolve around the world and Ghana educational system is not different. Apart from curriculum policies, one major reason for revolving policies is to increase the intake of leaner numbers (Acedo, 2008). One of such policy was the established Free Compulsory Universal Basic Education (FCUBE) policy by the government of Ghana in 2006 which reported a significant increase of school enrolment (Darvas \& Balwanz, 2014). To give opportunity for the many basic school leavers to gain entrance into second cycle education as a result of the FCUBE, the government of Ghana introduced the free Senior High School (SHS) policy (Mensah, 2019). Enrolment into free senior high schools during its first implementation for first years increased by almost $63 \%$ (Mensah, 2019) with 33.2\% increment reported for overall enrolment. As a result of the large enrolment, a lot of pressure was put on the current resources available (Deho \& Agangiba, 2019). The inadequate resources to accommodate the large numbers within the scheduled academic calendar prompted the definition of the twofold track instruction framework (Mensah, 2019). This arrangement necessitates that the whole students and staff be partitioned into two tracks, with the end goal that, while one track is in school, the other is on vacation (Mensah, 2019). While this method was a laudable one, keeping students unengaged lead to an outcry of this system as concern was raised especially by parents who had their wards in final year of schools.

Promoting outreach to students on holidays with learning opportunities through technology could help complement the inadequate resources. At the senior high school level of Ghana, the Ministry of Education (MOE) and Ghana Education Service (GES) have begun to coordinate ICT as a subject of concentration in the educational plan. Recently, there has been a call on the introduction of an electronic learning programme to complement the double- 
track system introduced in the country's SHS (Essah-Hienoo, 2018). This could afford students the opportunity to access recorded lectures on various topics and soft copies of other educative materials on a public online portal to prevent students from losing focus on their academic agenda. While there is a great deal of knowledge about how WhatsApp as a lever is used for having access to cooperatively-created resources, heightening on assignment conduct and promoting important context-free learning (Rambe et al., 2013), there is paucity of data in relation to WhatsApp and its application for instruction in Ghana. The implementation of the double track senior high school system has no doubt improved access to senior high schools however the challenges associated with it remain daunting (Deho \& Agangiba, 2019; Mensah, 2019) and as such, any innovative ways to academically reach students and keep them occupied cannot be overstated. WhatsApp has been used as a platform to complement other instructional delivery methods (Bouhnik \& Deshen, 2014; Smith, 2015) and it with this background that this current study proposed to determine senior high school teachers perception of the use of WhatsApp messenger for teaching and learning. This study aimed at gaining understanding into the WhatsApp messenger and intention to use it for teaching and learning. Specifically, the study aimed to advance understanding of the antecedent factors: perceived cost, perceived trust, perceived usefulness, perceived convenience, perceived effectiveness, the effect between them and the extent of these effect on the intention to use it for teaching and learning among senior high school teachers.

\section{LITERATURE REVIEW AND HYPOTHESES DEVELOPMENT}

\section{Perceived Cost (PCT)}

Studies have used TAM in the prediction of technology acceptance as this model has been validated and believed to be prominent in the examination of technology adoption (Park et al., 2014; Purnomo \& Lee, 2013). TAM has been further extended with several sets of acceptance determinants for developing subsequent prominent models capable of better predicting user's behaviour across different fields of application (Venkatesh et al., 2012). Cost, inadequate infrastructure and human capabilities have been identified as other variables of TAM (Harfoushi \& Obiedat, 2011; Nneka, 2010). Perceived cost also referred to as perceived value (Kim et al., 2019) is incurred in the process of technology acquisition or adoption (Machogu \& Okiko, 2012) which might include but not limited to the cost of hardware, stable supply of power, employment and retaining technicians as well as e-training (Zainab et al., 2017) and planning, organizing and putting the new system into practice (Machogu $\&$ Okiko 2012). For instance, the standard of e-training platforms to be provided is contended to be affected by cost (Özbek et al. 2015) due to these relative costs associated with a technology adoption (Machogu \& Okiko 2012). Also, the standard of electronic training platforms to be provided is contended to be affected by cost (Özbek et al., 2015). Several studies have investigated perceived cost and intention to use
(Sobti, 2019; Kim, et al., 2019). In the health sector for instance Cajita et al (2017) investigated features that influence the use of mHealth among patients with heart failure and identified that perceived cost was not associated with intention to use. In the financial sector Yang et al (2012) investigated the use of mobile payments system in China and found relative advantage as the most important factor and perceived cost as the least important factor. On the contrary, Zainab et al (2017) showed that perceived cost to have a significant effect on e-training adoption. An outcome further reiterated in a study conducted by Sobti (2019) who identified that perceived cost significantly correlate with behavioural intention. The benefits of online learning include low cost of technology (Almahasees et al., 2021) and the low cost that might be associated with the usage of WhatsApp messenger in a complementary nature with instruction could promote its usage. For the purpose of the hypotheses related to cost, this current study assumed that SHS teachers might presume that: a) the extra cost that might be incurred by management of schools might lead to some resistance (less trust) in supporting the future use of WhatsApp for complementary instruction and b) there is low cost associated with using WhatsApp for instruction, hence, teachers might perceive it as effectiveness, usefulness, convenient and subsequently have the intention to use it future support are rendered for its usage. As such, this current study hypothesized that:

H1: Perceived cost associated with WhatsApp usage for teaching has a negative effect on SHS teachers perceived trust.

H2: Perceived cost associated with WhatsApp usage for teaching has a positive effect on SHS teachers' perceived effectiveness.

H3: Perceived cost associated with WhatsApp usage for teaching has a positive effect on SHS teachers' perceived convenience.

H4: Perceived cost associated with WhatsApp usage for teaching has a positive effect on SHS teachers' perceived usefulness.

H5: Perceived cost associated with WhatsApp usage for teaching has a positive effect on SHS teachers' perceived intention to use.

\section{Perceived Effectiveness (PE)}

The use of computers, mobile devices, and the Internet is at its highest level to date and expected to continue to increase as technology becomes more accessible, particularly for users in developing countries (Poushter, 2016). It has been an instrument for achieving social, economic, educational, scientific and technological development (Adedeji, 2010).The application of Information Communication Technology (ICT) is not only emphasized in corporative business and the industrial sector, but it is an essential part of education at all levels (Allen, 2011). Since the 1900s, administrators and faculty have grappled with how to effectively use technical innovations such as video and audio recordings, email, and teleconferencing to augment or replace traditional instructional delivery methods (Kaware \& Sain, 2015; 
Westera, 2015). Many previous researches have proven that the usage of ICT in teaching and learning process could improve students' achievement (Nakayima, 2011, JamiesonProctor, et al., 2013). Effective use of technology requires proper integration to make it more productive and foster educational development which also entails proper utilization of information resources and the technology that promote its usage (Erişti et al., 2012, p.30). Perceived effectiveness has been defined in several literature. For instance, Coursaris et al (2012) referred to it as the ability of users to complete tasks using the technology, and the quality of output of those tasks. Also, perceived effectiveness of technology use has been further expanded by the work of Lowerison et al., (2006, p. 468), In this context we define perceived effectiveness as the tendency of technology to have a persuading impact on its users. Social media technologies such as WhatsApp is at its highest level and expected to continue to increase as the social media becomes more accessible, particularly for users in developing countries (Poushter, 2016). Several studies support the effectiveness of social media for achieving educational goals (Blaschke, 2014; Ihlebæk \& Larsson, 2018; Li, 2017; Moghavvemi et al., 2018). For instance, self-perceived effectiveness has also been reported to significantly influence the intention to use mobile medical apps among older adults (Askari et al., 2020). With the proliferation of social media and the debate over the cost of educational technologies will linger (Moyle, 2007), several students use their own technology to support their learning. At their own time students use technology to share knowledge, confirm their knowledge and to share learning resources. the opportunities that social media technologies present for teaching and learning in schools is enormous (Kaware \& Sain, 2015; Westera, 2015). Though some studies suggest that the distractive nature of technology is likely to affect its effectiveness for teaching and learning (Coursaris, et al., 2012). We are of the view that effectiveness of digital technology for learning can be influenced by the teachers' pedagogical praxis, the interactivity of the learning, the quality of the learning system (Liaw, 2008). WhatsApp has proven to be interactive, and support the collaborative learning tenets. Moreover, younger people and students who have used social media to support their learning are more likely to confirm the effectiveness of social media for teaching and learning (Suka et al., 2017) and as such, this current study hypothesized that:

H6: Perceived effectiveness associated with WhatsApp usage for teaching has a positive effect on SHS teachers' perceived usefulness.

H7: Perceived effectiveness associated with WhatsApp usage for teaching has a positive effect on SHS teacher's perceived intention to use.

\section{Perceived Convenience (PC)}

In terms of user evaluation of service experiences, the term convenience refers to an individual's preference for convenient product and services (Hsu \& Chang.2013). Convenience can also be viewed as the use of an information system or technology by five dimensions namely: time, place, acquisition, use, and execution (Brown. 1989). The 'ease of use' is reported as a determinant of the convenience construct and as such perceived ease of use positively influences users' perception of convenience in the usage of a technological system (Brown, 1989).

Convenience to use have been identified as predictor of intention to use in the business and tourism sector. For instance Chen and Tsai (2019) integrated TAM and Information system success model to present a model that explores users' intention to use a personalized location-based mobile tourism application and established that perceived convenience had significant influence on intention to use the application. Not only has perceived benefit of using technology been associated with convenience of using the technology (Kvavik, 2005) but perceived convenience has been cited as an antecedent factor that affect intention to use a mobile technology or system (Gupta \& Kim, 2007). Contrary, Yoon and Kim (2007) are of the view that convenience in accessing technology is not definitely related to intention to use technology, and convenience in use is similar to ease of use in TAM. However, Hossain and Prybutok (2008) proposed that convenience include both ease of use and usefulness. A study on investigating English learning through PDAs showed a significant positive effects of perceived ease of use on perceived convenience, perceived convenience on perceived usefulness, and perceived convenience on attitude toward using PDAs (Chang et. al., 2012). Therefore, relationships between perceived convenience and TAM variables require further examination; while this is not the focus of the current study, we operationalized perceived convenience in the study based on the perspective provided by Yoon and Kim (2007). Consequently, we defined perceived convenience as a level of convenience toward time, place and execution that one feels when using WhatsApp for instruction purposes. Thus, if one could perform a task at any time, perform the task at any place or perform a task with ease when using the WhatsApp, then he or she feels more convenient toward time, place and execution respectively. Accordingly, the study advocates that favourable perceived convenience of WhatsApp use will promote high acceptance and usage, thus, this current study hypothesized that:

H8: Perceived convenience associated with WhatsApp usage for teaching has a positive effect on SHS teachers' perceived usefulness.

H9: Perceived convenience associated with WhatsApp usage for teaching has a positive effect on SHS teachers' perceived intention to use.

Technology adoption model (TAM): Perceived Usefulness (PU)

The features and characteristics of TAM are reported to serve as variables to determine whether a system will be accepted or rejected (Suorsa \& Eskilsson, 2014) and has been verified in this regard in various studies (Buabeng-Andoh, 2021; Durodolu, 2016; Lai, 2017a; Lai, 2017b; Lai \& Zainal, 
2015; Rafique, et al., 2020). Other research has confirmed that TAM is a valid model that represents an important theoretical framework to explain and predict technology acceptance behaviour (Al-Gahtani, 2014; Hsia et al., 2014; Lee et al., 2014; Tarhini et al., 2014; Wu \& Zhang, 2014). One of the important constructs in TAM is reported to be perceived usefulness (Chen et al., 2019) and has proven to be a very important factor for technology adoption in most recent studies (Yeh \& Teng, 2011). For instance, PU is reported to be positively associated with continuance intention in the context of e-text (Baker-Eveleth \& Stone, 2015; Stone \& Baker-Eveleth, 2013), instant messaging (Wang et., 2011), mobile service provider (Abbas \& Hamdy, 2015), online travel services (Li \& Liu, 2014), e-learning (Lin \& Wang, 2012). blog learning (Tang et al. 2012) and predictor of behavioural intention to use technology of interest (Park, et al., 2014; Buabeng-Andoh, 2021). In this current study context, PU is explained as the belief that SHS teachers have in the usefulness of WhatsApp to support their teaching and learning outcomes while the construct intention to use is presented as behavioural intention to use WhatsApp. Considering that WhatsApp remains one of the most popular social media app for messaging and sharing of information and resources within the learning environment, this current study hypothesized that:

H10: Perceived usefulness of WhatsApp for teaching has a positive effect on SHS teachers' perceived intention to use.

\section{Perceived Trust (PT)}

The universal definition of trust remains debatable (Gefen et al., 2003) due to the diverse definitions related to the various disciplines viewpoint of trust (Setiawan \& Achyar, 2012). Not only has trust and familiarity have been cited to influence E-commerce (Maqableh, et al., 2015) but ease of use, usefulness, attitude, trust and risk has been reported to increase the intention of use (Liébana-Cabanillas, et al., 2014). Customer trust been reported to play a critical role in hindering fears related to using mobile internet services as well as motivating customers to adopt such systems (Hollingsworth \& Dembla, 2013; Sadi \& Noordin, 2011). Other studies have also support the role of trust in shaping a positive customer perception about the values and benefits of using mobile internet (Aloudat, et al., 2014; Zarmpou et al.,2012). Perceived trust has not only been found to be positively related to perceived usefulness of m-banking (CruzBenito et al., 2019) but also have been cited to have a positive association with perceived continuance intention to use the payment platforms (Shao, et al., 2019; Aref \& Alshahri, 2021). Teachers perceiving that they might receive future supporting in using WhatsApp as a complementary instruction medium might have the perceive intention to use this technology as a complementary means of instruction. Little is known about it's effect on the use of social media in teaching and learning. research is clearly needed to examine the effect of trust on teachers' intention to use WhatsApp for teaching and learning. Based on the above review, this current study hypothesized that:
H11: Perceived trust associated with WhatsApp usage for teaching has a positive effect on SHS teachers' perceived intention to use.

Figure 1 represented the theoretical model of the study.

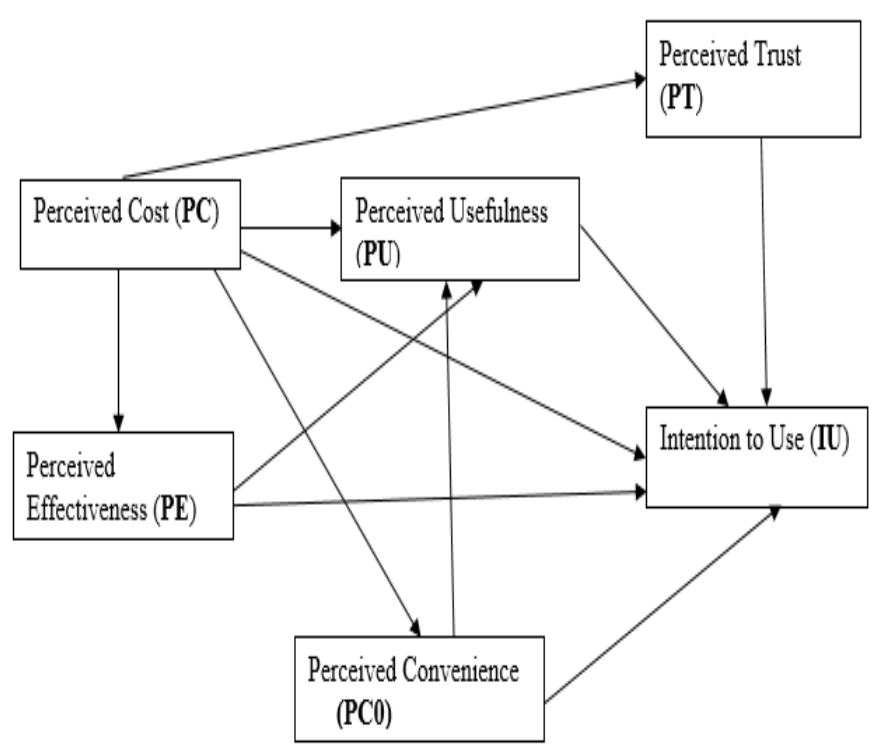

Figure 1: Research Model

\section{METHODS}

\section{Study design and sample}

A cross-sectional study (Pelham \& Blanton, 2006) was conducted among 213 SHS teachers obtained purposively (Johnson \& Onwuegbuzie, 2004) based on Yamane (1973) formulae within an industrial Metropolis of the capital Ghana. The industrial metropolis is among the most well-organized communities in Ghana with some of the well-resourced senior high schools in Ghana. Of the 6 schools, 1 school was purposively used as a pilot study site due to its obscured location.

The data was collected online through participants schools' listserv. Majority of the respondents were between the ages of 31-36 year $(\mathrm{n}=91)$ and teaching experience between 11-15 years $(\mathrm{n}=97)$. These participants $(81 \%, \mathrm{n}=172)$ had high levels of access to digital technologies (particularly smart phones) with all of them as WhatsApp users.

\section{Data Collection and Instrument}

The study was a self-reported survey that utilized questionnaire as an instrument for data collection. Prior to data collection, Institutional Review Board approval was sought as well as a pilot study conducted to validate the questionnaire. The questionnaire was made up of two main sections, sections A and B. Section A sought demographic information of the respondents. Section B contained the 25 scale items for the latent variables namely Perceived Usefulness (PU), 
Table 1: Operational Definitions for Latent Variables of the Study and Measured Items

\begin{tabular}{|c|c|c|}
\hline $\begin{array}{c}\text { Latent } \\
\text { Variable }\end{array}$ & $\begin{array}{c}\text { Operational } \\
\text { definition }\end{array}$ & Measured Items \\
\hline \multirow[t]{5}{*}{$\begin{array}{c}\text { Perceived } \\
\text { Usefulness } \\
\text { (PU) } \\
\end{array}$} & \multirow{5}{*}{$\begin{array}{l}\text { Extent to which } \\
\text { teachers enhance } \\
\text { their learning } \\
\text { (performance } \\
\text { and productivity } \\
\text { of the lesson) via } \\
\text { WhatsApp }\end{array}$} & $\begin{array}{l}\text { PU01: Using WhatsApp can improve } \\
\text { the delivery of my course. }\end{array}$ \\
\hline & & $\begin{array}{l}\text { PU02: Using WhatsApp can improve } \\
\text { my productivity in my course delivery. }\end{array}$ \\
\hline & & $\begin{array}{l}\text { PU03: Using WhatsApp can enable me } \\
\text { to have more accurate information for } \\
\text { my students. }\end{array}$ \\
\hline & & $\begin{array}{l}\text { PU04: Using WhatsApp can make it } \\
\text { easier to do my tasks as an instructor. }\end{array}$ \\
\hline & & $\begin{array}{l}\text { PU05: Using WhatsApp is useful in } \\
\text { my study. }\end{array}$ \\
\hline \multirow[t]{5}{*}{$\begin{array}{c}\text { Perceived } \\
\text { Effectiveness } \\
\text { (PE) } \\
\end{array}$} & \multirow{5}{*}{$\begin{array}{l}\text { The extent to } \\
\text { which } \\
\text { WhatsApp } \\
\text { enhanced the } \\
\text { delivery of the } \\
\text { lesson in terms } \\
\text { of organising } \\
\text { content and other } \\
\text { technologies }\end{array}$} & $\begin{array}{l}\text { PE01: WhatsApp can make content of } \\
\text { the lesson to be well delivered. }\end{array}$ \\
\hline & & $\begin{array}{c}\text { PE02: WhatsApp can make } \\
\text { organization of the lesson appropriate, } \\
\text { logical and clear. }\end{array}$ \\
\hline & & $\begin{array}{l}\text { PE03: WhatsApp can ensure that the } \\
\text { lesson was well supported by } \\
\text { examples. }\end{array}$ \\
\hline & & $\begin{array}{l}\text { PE04: The activities within WhatsApp } \\
\text { makes me identify the importance of } \\
\text { learning with the aid of technology. }\end{array}$ \\
\hline & & $\begin{array}{l}\text { PE05: I feel empowered by using } \\
\text { WhatsApp. }\end{array}$ \\
\hline $\begin{array}{c}\text { Perceived } \\
\text { Convenience }\end{array}$ & \multirow{5}{*}{$\begin{array}{l}\text { The level of } \\
\text { convenience } \\
\text { toward time, } \\
\text { place and } \\
\text { execution that } \\
\text { one feels when } \\
\text { pursuing a task } \\
\text { via the } \\
\text { WhatsApp }\end{array}$} & PCo01: WhatsApp is easy to use. \\
\hline \multirow[t]{4}{*}{ (PC) } & & $\begin{array}{l}\text { PCo02: It is easy to get WhatsApp to } \\
\text { do what I want it to. }\end{array}$ \\
\hline & & $\begin{array}{l}\text { PCo03: Using WhatsApp can improve } \\
\text { my objectives for clear and } \\
\text { understandable course delivery. }\end{array}$ \\
\hline & & $\begin{array}{l}\text { PCo04: Interacting with WhatsApp } \\
\text { does not require a lot of mental effort. }\end{array}$ \\
\hline & & $\begin{array}{l}\text { PCo05: It is easy to find information } \\
\text { through the usage of WhatsApp. }\end{array}$ \\
\hline \multirow[t]{2}{*}{$\begin{array}{l}\text { Perceived } \\
\text { Trust (PT) }\end{array}$} & \multirow{2}{*}{$\begin{array}{l}\text { The level of } \\
\text { expectation or } \\
\text { support about the } \\
\text { future behavior. }\end{array}$} & $\begin{array}{l}\text { PT01: My school would provide } \\
\text { means for internet for using WhatsApp } \\
\text { messenger for teaching. }\end{array}$ \\
\hline & & $\begin{array}{l}\text { PT02: My school would provide } \\
\text { means for obtaining an electronic } \\
\text { device for teaching. }\end{array}$ \\
\hline \multirow[t]{2}{*}{$\begin{array}{c}\text { Perceived } \\
\text { Cost }(\text { PCT })\end{array}$} & \multirow{2}{*}{$\begin{array}{c}\text { The cost } \\
\text { incurred in as a } \\
\text { result of } \\
\text { WhatsApp usage }\end{array}$} & $\begin{array}{l}\text { PCT01: Using WhatsApp could mean } \\
\text { internet cost for me. }\end{array}$ \\
\hline & & $\begin{array}{l}\text { PCT02: Using WhatsApp could mean } \\
\text { obtaining an electronic device. }\end{array}$ \\
\hline
\end{tabular}

Table 2: Cont.

\begin{tabular}{|c|c|c|}
\hline $\begin{array}{c}\text { Latent } \\
\text { Variable }\end{array}$ & $\begin{array}{c}\text { Operational } \\
\text { Definition }\end{array}$ & Measured items \\
\hline \multirow[t]{6}{*}{$\begin{array}{l}\text { Intention } \\
\text { to Use } \\
\text { (IU) }\end{array}$} & \multirow{6}{*}{$\begin{array}{l}\text { The desire to } \\
\text { use WhatsApp } \\
\text { to teach in the } \\
\text { future }\end{array}$} & $\begin{array}{l}\text { IU01: I can use WhatsApp to get more } \\
\text { information from colleagues concerning } \\
\text { my subject. }\end{array}$ \\
\hline & & $\begin{array}{l}\text { IU02: WhatsApp can provide an } \\
\text { attractive working environment. }\end{array}$ \\
\hline & & $\begin{array}{l}\text { IU03: Using WhatsApp can be a } \\
\text { pleasant experience. }\end{array}$ \\
\hline & & $\begin{array}{l}\text { IU04: I believe it will be a good. idea to } \\
\text { use WhatsApp for teaching my courses. }\end{array}$ \\
\hline & & $\begin{array}{l}\text { IU05: Knowing how to use any form of } \\
\text { electronic device is a worthwhile skill. }\end{array}$ \\
\hline & & $\begin{array}{l}\text { IU06: I have a generally favourable } \\
\text { attitude towards using WhatsApp as a } \\
\text { cheaper means of instruction. }\end{array}$ \\
\hline
\end{tabular}

Perceived Cost (PCo), Perceived Effectiveness (PE), Perceived Trust (PT), Perceived Convenience (PC) and Intention to Use (IU). Questions based on Perceived Usefulness was adapted from Davis (1989). Items on Perceived Cost and Intention to use were adapted from Özbek et al (2015), Perceived Effectiveness was adapted from the work of Lowerison, et al., (2006). Items under the Perceived Trust were adapted form Maqableh et al (2015). Finally items under the Perceived Convenience were adapted from Yoon and Kim (2007). The operational definitions for latent variables of the study and measured items are summarized in table 1.

\section{Data Analysis}

IBM Statistics 25.0 was used for descriptive analysis and IBM AMOS 22.0 was then, employed for the structural equation modelling technique. A Cronbach alpha coefficient of .909 was obtained for the pilot study. This value was above 0.70 and deemed acceptable (Warner, 2013). For all the latent variables, a four-point Likert scale $(1=$ strongly disagree, $4=$ strongly agree) was used. The scores were interpreted as follows: 1 is the lowest possible score, which represents a very strong negative perception, while 4 is the highest possible score which represents a very strong positive perception. Table 2 shows the reliability analysis and convergent validity of items of the constructs for the latent variables used in the study.

Table 2: Reliability Analysis and Convergent Validity of Items of the Constructs

\begin{tabular}{|c|c|c|c|c|c|c|c|c|c|c|}
\hline Latent Variable & Mean & SD & AVE & CR & $\mathbf{1}$ & $\mathbf{2}$ & $\mathbf{3}$ & $\mathbf{4}$ & $\mathbf{5}$ & $\mathbf{6}$ \\
\hline $\begin{array}{c}\text { 1Perceived } \\
\text { Usefulness }\end{array}$ & 3.1936 & .5351 & .608 & .885 & $(.844)^{*}$ & & & & & \\
\hline 2Perceived Cost & 3.4040 & .6080 & .600 & .744 & .561 & $(.744)^{*}$ & & & \\
\hline $\begin{array}{c}\text { 3Perceived } \\
\text { Effectiveness }\end{array}$ & 3.1328 & .5541 & .652 & 737 & .567 & .287 & $(.831)^{*}$ & & & \\
\hline 4Perceived Trust & 2.2000 & 1.0865 & .910 & .952 & .110 & -.251 & .151 & $(.901)^{*}$ & & \\
\hline $\begin{array}{c}\text { 5Perceived } \\
\text { Convenience }\end{array}$ & 3.1328 & .5541 & .748 & .805 & .200 & .290 & .293 & .301 & $(.782)^{*}$ & \\
\hline 6Intention to Use & 3.4933 & .4856 & .640 & .761 & .500 & .744 & .736 & .088 & .381 & $(.864)^{*}$ \\
\hline
\end{tabular}

*Cronbach's Alpha 


\section{RESULTS}

The mean, standard deviation, reliability values, and the convergent validity of items of the latent variables, and correlations between these variables are presented in Table 2 . The Cronbach's alpha values were at least 0.7 and deemed as high reliability (Nunnally \& Bernstein, 1994). Exploratory factor analysis (EFA) of variables related to the items of the survey were assessed. Results, reported a KMO value of .880 (Sharma, 1996), and Bartlett's Test of Sphericity was significant (Eyduran, Topal \& Sonmez, 2010), an indication that the sample of the study was adequate to perform EFA. The EFA results reported factor weights of items with total explained variance with five factors was 83.593. Summary of EFA results were presented in Table 3. Composite reliability (CR) and average variance extracted (AVE) values were presented (Table 2). Values for CR and AVE were higher than 0.7 (Hair et al., 2010) and 0.5 (Fornell \& Larcker, 1981) respectively. Based on the $\mathrm{CR}$ and AVE values which estimated convergent validity (Hair et al., 2010) the research model was tested with structural equation modeling (SEM). The results of SEM were demonstrated in Figure 2.

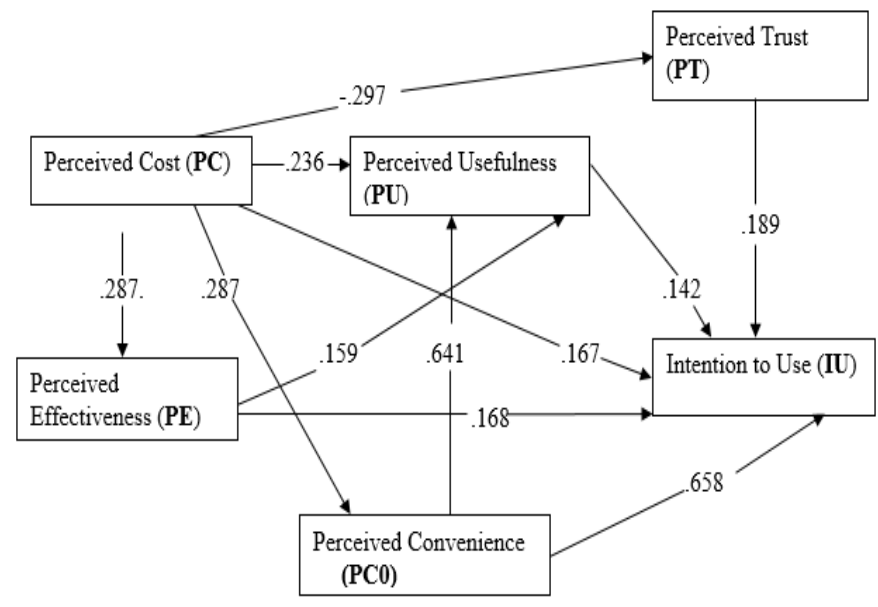

Figure 2: Result model
Table 3: Exploratory Factor Analysis Results

\begin{tabular}{|c|c|c|c|c|c|c|}
\hline Measured Items & & & & & & \\
\hline PU01 & .625 & & & & & \\
\hline PU02 & .756 & & & & & \\
\hline PU03 & .639 & & & & & \\
\hline PU04 & .571 & & & & & \\
\hline PU05 & .618 & & & & & \\
\hline PE01 & & .400 & & & & \\
\hline PE02 & & .582 & & & & \\
\hline PE03 & & .709 & & & & \\
\hline PE04 & & .532 & & & & \\
\hline PE05 & & .592 & & & & \\
\hline PC01 & & & .766 & & & \\
\hline PC02 & & & .730 & & & \\
\hline $\mathrm{PC} 03$ & & & .750 & & & \\
\hline PC04 & & & .703 & & & \\
\hline PC05 & & & .563 & & & \\
\hline PT01 & & & & .559 & & \\
\hline PT02 & & & & .713 & & \\
\hline PCT01 & & & & & .660 & \\
\hline РCT02 & & & & & .610 & \\
\hline IU01 & & & & & & .590 \\
\hline IU02 & & & & & & .798 \\
\hline IU03 & & & & & & .545 \\
\hline IU04 & & & & & & .627 \\
\hline IU05 & & & & & & .884 \\
\hline IU06 & & & & & & .876 \\
\hline
\end{tabular}

Analysis of the model's goodness of fit indices indicated a model structure that well fitted the SEM (CMIN/DF: 2.563, p: .073 , SRMR: .034, RMSEA: .056, CFI: .935, TLI: .941, GFI: .971, NFI: .961) (Bentler, 1990; Hair et al., 2010). Table 4 summarized the results of the models' hypotheses.

Table 4: Structural Equation Modeling Results

\begin{tabular}{|c|c|c|c|c|c|}
\hline Hypotheses & Independent variable & Dependent Variable & Standardized $\beta$ & Sig & Results \\
\hline 1 & Perceived cost & Perceived trust & -.297 & .000 & Fail to reject \\
\hline 2 & Perceived cost & $\begin{array}{c}\text { Perceived } \\
\text { effectiveness }\end{array}$ & .287 & .000 & Fail to reject \\
\hline 3 & Perceived cost & Perceived convenience & .287 & .000 & Fail to reject \\
\hline 4 & Perceived cost & Perceived usefulness & .236 & .001 & Fail to reject \\
\hline 5 & Perceived cost & Intention to use & .167 & .006 & Fail to reject \\
\hline 6 & Perceived effectiveness & Perceived usefulness & .159 & .010 & Fail to reject \\
\hline 7 & Perceived effectiveness & Intention to use & .168 & .004 & Fail to reject \\
\hline
\end{tabular}


International Journal of Research and Innovation in Social Science (IJRISS) |Volume VI, Issue I, January 2022 |ISSN 2454-6186

\begin{tabular}{|c|c|c|c|c|c|}
\hline 8 & Perceived convenience & Perceived usefulness & .641 & .000 & Fail to reject \\
\hline 9 & Perceived convenience & Intention to use & .658 & .000 & Fail to reject \\
\hline 10 & Perceived usefulness & Intention to use & .142 & .014 & Fail to reject \\
\hline 11 & Perceived trust & Intention to use & .189 & .003 & Fail to reject \\
\hline
\end{tabular}

The first hypothesis of the research assumed that perceived cost would negatively affect perceived trust. The results showed that perceived cost negatively affected perceived trust $(\beta=-.297)$, thus the $\mathrm{H} 1$ was supported. The next four hypotheses of the research assumed that the perceived cost would positively affect perceived effectiveness, perceived usefulness, perceived convenience and intention to use. The results indicated that cost perception positively affects perceived effectiveness $(\beta=.287)$, perceived usefulness $(\beta=$ $.236)$, perceived convenience $(\beta=.287)$ and intention to use $(\beta=.167)$. Thus, $\mathrm{H} 2, \mathrm{H} 3, \mathrm{H} 4$ and $\mathrm{H} 5$ were accepted. Two more hypotheses of the research also assumed that the perceived effectiveness would positively affect perceived usefulness and perceived intention to use. The result indicated perceived effectiveness positively affected perceived usefulness and intention to use with $\beta$ values of .159 and .168 respectively. These two hypotheses (H6 \& H7) were accepted. A further two hypotheses of the research (H8 \& H9) further assumed that the perceived convenience would positively affect perceived usefulness and perceived intention to use. The result supported these hypotheses with reported $\beta$ values of .641 and .658 respectively. Perceived usefulness was further hypothesized to positively have an effect on perceived intention and this hypothesis, H10, was accepted with a $\beta$ value of .142. The final hypothesis, H11, assumed that the perceived trust would affect perceived intention to use. The results showed that perceived trust positively affected perceived intention to use $(\beta=.189)$, thus the H11 was also supported.

\section{DISCUSSIONS}

The current study proposed to determine senior high school teachers perception of the use of WhatsApp as complementary instruction medium. Results based on SEM, reported a goodness of fit of the indices of the research model were within the acceptable limits, and all developed hypotheses were supported. The most interesting finding of the study was that perceived convenience demonstrated the expected effects on both perceived usefulness and perceived intension to use the technology. Thus, the results showed that the convenience associated with using WhatsApp messenger caused the perceive usefulness of the technology and teachers subsequent perceived intention to use the technology for teaching ( H8 \& H9). Convenience to use have been identified as predictor of intention to use a technology (Chen \& Tsai, 2019; Baek et al., 2008). These effect could be as a result of this present study participants viewing the convenience in relations to place, time, and execution. For instance, Chang et al (2012) investigated English learning through PDAs and identified significantly positive effects of perceived ease of use on perceived convenience, perceived convenience on perceived usefulness, and perceived convenience on attitude toward using PDAs.

Participants perceived cost associated with using WhatsApp messenger on perceive trust demonstrated a negative impact on the perceived trust in participants level of expectation or support they might receive in the future in order to use technology for teaching (H1). While the role of trust in shaping a positive perception about the values and benefits of using a technology (Aloudat et al., 2014; Zarmpou et al., 2012; Zhang et al., 2010), the perceived cost involved in the acquisition of the system usage by institutions (Machogu \& Okiko, 2012) might resulted in the participants less trusting that they might have support to implement the usage of the technology for teaching. Cost, inadequate infrastructure and human capabilities have been identified as other variables of technology acceptance model (Harfoushi \& Obiedat 2011; Nneka Eke, 2010). Also, perceived cost has been argued to be a barrier to technology usage and adoption (AlSoufi \& Ali 2014; Fonchamnyo, 2013). For instance, Zainab, et al (2017) researched into factors affecting e-training adoption among 450 heads of department in 27 federal ministries in Nigerian and revealed that perceived cost had a significant effect on etraining adoption.

Comparatively, senior high teachers believing that the less cost associated with using WhatsApp messenger for teaching could promote teaching that will be effective $(\mathrm{H} 2)$, convenient (H3), useful (H4) and subsequently their perceived intention to use (H5) this technology for teaching. These outcomes further reiterates majority of the participants having access to high levels of technology and all of them being WhatsApp users. This finding is congruent with Sobti (2019) who identified that perceived cost significantly correlate with behavioural intention. The relation between cost and benefit pay a significant role to both perceived usefulness and ease of use (Lule, 2008). People perception of an acceptable cost of technology may adopt it more easily and then use it (Micheni et al., 2013). It is reported that social media technologies such as WhatsApp is at its highest level and is expected to continue to increase as the social media becomes more accessible, particularly for users in developing countries (Poushter, 2016). Schools have long been concerned about the convenient access (Levin \& WadMany, 2008), and convenient use of technology for preparing and reusing digital learning materials (Baek et al., 2008) which this technology could 
provide. Furthermore, perceived usefulness and ease to use have direct effect on intention to use technology of interest (Park, et al., 2011; Buabeng-Andoh, 2021).

Perceived effectiveness has been defined as the ability of users to complete tasks using the technology, and the quality of output of those tasks (Coursaris, et al., 2012). At their own time students use technology to share knowledge, confirm their knowledge and to share learning resources. The opportunities that social media technologies present for teaching and learning in schools is enormous (Kaware \& Sain, 2015; Westera, 2015). Effectiveness of digital technology for learning can be influenced by the teachers pedagogical praxis, the interactivity of the learning, the quality of the learning system (Liaw, 2008). An assertion that might have influenced participants of this current study to demonstrate an effect of perceived effectiveness on both perceived usefulness (H6) and intention to use (H8). Moreover, younger people and students who have used social media to support their learning are more likely to confirm the effectiveness of social media for teaching and learning (Suka et al., 2017). A characteristics these participants have with majority of them being between the ages of 31 to 36 .

Perceived Usefulness is one of the crucial determinants among many variables that influence system use (Davis, 1989) and has been cited in numerous studies as a very important factor for technology adoption (Chen et al., 2019; Buabeng-Andoh, 2021; Yeh \& Teng 2011). In adopting a new system, it is stated that the ease of use of the system has a strong impact on the end users' perception of its usefulness (Ma \& Liu, 2005). Furthermore, perceived usefulness is a significant predictor of user adoption behaviour (Chitungo \& Munongo, 2013; Marumbwa \& Mutsikiwa, 2013), an assertion reiterated by this current study (H10).

The intention of a user to engage in the usage of a technology is also dependent on the levels of trust in a service provider (Masinge, 2010). The outcome of this study revealed an effect of trust, that is, the level of expectation or support about the future usage of the technology on perceived intention to use (H11). Perceived trust of the customers has been reported to be positively associated with perceived continuance intention to use payment platforms (Aref, \& Alshahri, 2021; Shao, et al., 2019). This outcome is also consistent with the works of Chitungo and Munongo (2013) who reported perceived trust to have a significant influence on the adoption of mobile financial services.

\section{CONCLUSION}

The current study proposed to determine senior high school teachers perception of the use of WhatsApp as complementary instruction medium. The study revealed perceived convenience as a major factor that demonstrated the perception of the usefulness and subsequent intention to use WhatsApp messenger for teaching. With the current school calendar which follows a double track system where a section of students are home while others are in school, the use of WhatsApp to promote convenient learning especially for those at home cannot be overstated. Ultimately for an effective students engagement, WhatsApp could promote a convenient and useful means that can complement other methods or medium of lesson delivery. It will be prudent to have management/stakeholders of schools to encourage or institute a policy for the use of this technology by providing resource that can necessitate its usage, especially with all the respondents having diverse technological devices and are user of the WhatsApp messenger. Such a policy could reiterate Mensah (2019) assertion of promoting long term benefits aimed at improving the human capital base of the country through an increase in the level of literacy among the Ghanaian population, especially with the current increases in enrolments due to abolition of school fees.

While various studies have been conducted in terms of the application of social media platforms for teaching and learning, the paucity of data related to perceived cost, trust, convenience, effectiveness, and usefulness with respect to the intention to use WhatsApp messenger for teaching might affirm that the current study is unique in this respect, and as such it is expected to contribute to literature crucially. This study was limited in some aspects. First, the participants of the study were only from one Metropolis within a region in Ghana. As a result, generalization of the findings should be done consciously. This is the case because, diverse findings could be derived from participants from different metropolis within the regions around the country.

With the current popularity in online classes, WhatsApp grants both the teacher and students diverse ways to engage each other through direct communication. As such, it is paramount for heads of high schools to encourage the use of this social media tool by providing resources that can promote its usage for academic purposes and as such, there is also the need to facilitate guidelines in order to formulate strategic ways of using WhatsApp messenger for collaborative learning among students. Extending this research within other parts of the country in the future will contribute not only to the literature, but will enhance the validity of the model as well as present senior high teachers view on the application of social media for instructions. Second, using a cross-sectional type of study may report findings which may not be applicable in the future because people perception changes as they progress in the adoption journey as a result this study recommends a longitudinal research to be conducted in order to better understand the influences of teachers continuance to use technology for instruction.

\section{REFERENCES}

[1] Abbas, H. A. \& Hamdy, H. I. (2015). Determinants of continuance intention factor in Kuwait communication market: Case study of Zain-Kuwait. Computers in Human Behavior, 49(0), 648-657

[2] Acedo, C. (2008). Inclusive education: pushing the boundaries. Prospects, 38, 5-13. 10.1007/s11125-008-9064-z.

[3] Adedeji, O.A. (2010). The Development of Modern Information and Communications technology in Ibadan: Creative Educational Publications Ltd. p. 58 
[4] Al-Gahtani, S. S. (2014). Empirical investigation of e-learning acceptance and assimilation: A structural equation model. Applied Computing and Informatics, doi:10.1016/j.aci.2014.09.001

[5] Allen, D. (2011). Information behavior and decision making in timeconstrained practice: A dual-processing perspective. Journal of the American Society for Information Science and Technology, 62(11), 2165-2181.

[6] Almahasees Z., Mohsen K. \& Amin M. O. (2021). Faculty's and students' perceptions of online learning during COVID-19. Front. Educ, 6, 1-10. DOI: 10.3389/feduc.2021.638470

[7] Aloudat, A., Michael, K., Chen, X., \& Al-Debei, M. M. (2014). Social acceptance of location-based mobile government services for emergency management. Telematics and Informatics, 31(1), 153-171.

[8] AlSoufi, A., \& Ali, H. (2014). Customers perception of mbanking adoption in kingdom of bahrain: an empirical assessment of an extended Tam model. International Journal of Managing Information Technology, 12, 14-29.

[9] Aref, M., \& Alshahri, N.B. (2021). The effect of introjected perceived locus of control and trust on intention to use ecommerce applications. Journal-International J. Adv. Comput. Syst. Softw. Eng., 1(2), 16-21.

[10] Askari, M., Klaver, N.S., van Gestel, T.J., \& van de Klundert, J. (2020). Intention to use medical apps among older adults in the Netherlands: Cross-sectional study. J Med Internet Res, 22(9, e18080. doi: 10.2196/18080

[11] Baek, Y., Jung, J., \& Kim, B. (2008). What makes teachers use technology in the classroom? Exploring the factors affecting facilitation of technology with a Korean sample. Computers \& Education, 50(1), 224-234.

[12] Baker-Eveleth, L., \& Stone, R., W. (2015). Usability, expectation, confirmation, and continuance intentions to use electronic textbooks. Behaviour \& Information Technology, 1-13.

[13] Barhoumi, C. (2015). The effectiveness of whatsapp mobile learning activities guided by activity theory on students' knowledge management. Contemporary Educational Technology, 6(3), 221-238.

[14] Bentler, P.M. (1990). Comparative fit indexes in structural models. Psychology Bulletin, 107, 238-46.

[15] Bouhnik, D., \& Deshen, M. (2014). WhatsApp goes to school: mobile instant messaging between teachers and students. Journal of Information Technology Education: Research, 13, v217-231.

[16] Blaschke, L. M. (2014). Using social media to engage and develop the online learner in self-determined learning. Research in Learning Technology, 22(1), 1-23.

[17] Brown, L. G. (1989). The strategic and tactical implications of convenience in consumer product marketing. Journal of Consumer Marketing 6(3), 13-19.

[18] Buabeng-Andoh, C. (2021). Exploring University students' intention to use mobile learning: A Research model approach. Education and information technologies, 26(1), 241256.

[19] Cajita, M. I., Hodgson, N. A., Budhathoki, C., \& Han, H. R. (2017). Intention to use mHealth in older adults with heart failure. The Journal of cardiovascular nursing, 32(6), E1

[20] Chang, C. C., Yan, C. F., \& Tseng, J. S. (2012). Perceived convenience in an extended technology acceptance model: Mobile technology and English learning for college students. Australasian Journal of Educational Technology, 28, 809-826.

[21] Chen, C. C., \& Tsai, J. L. (2019). Determinants of behavioral intention to use the Personalized Location-based Mobile Tourism Application: An empirical study by integrating TAM with ISSM. Future Generation Computer Systems, 96, 628-638.

[22] Chitungo, S.K. \& Munongo, S., 2013. Extending the Technology Acceptance Model to Mobile Banking Adoption in Rural Zimbabwe. Journal of Business Administration and Education, 3(1), 51-79.

[23] Coursaris, C. K., Hassanein, K., Head, M. M., \& Bontis, N. (2012). The impact of distractions on the usability and intention to use mobile devices for wireless data services. Computers in Human Behavior, 28(4), 1439-1449.
[24] Cruz-Benito, J., Sánchez-Prieto, J. C., Therón, R., \& GarcíaPeñalvo, F. J. (2019). Measuring students' acceptance to AI-driven assessment in eLearning: Proposing a first TAM-based research model. In P. Zaphiris \& A. Ioannou (Eds.), Learning and collaboration technologies. Design, experiences. 6th international conference, LCT 2019, held as part of the 21 st HCI international conference, HCII 2019, Orlando, FL, USA, July 26-31, 2019. Proceedings, part I (pp. 15-25). Springer Nature

[25] Darvas, P. \& D. Balwanz. (2014). Basic education beyond the millennium development goals in Ghana: How equity in service delivery affects educational and learning outcomes (No.: 978-14648-0098-6). Washington, DC: World Bank Studies

[26] Davis, F. (1989). Perceived usefulness, perceived ease of use and user acceptance of information technology. MIS Quarterly, 37(3), 319-340.

[27] Deho, O. B. \& Agangiba, W. A. (2019). Sentiment Analysis with Word Embedding: The Case of Double-track Education System in Ghana. Ghana Journal of Technology, 3(2), 51 - 57.

[28] Devi, K. S., Gouthami, E., \& Lakshmi, V. V. (2019). Role of Social Media in Teaching - Learning Process. Journal of Emerging Technologies and Innovative Research (JETIR), 6(1), 96-103.

[29] Durodolu, O. O. (2016). Technology Acceptance Model as a predictor of using information system ' to acquire information literacy skills. Library Philosophy and Practice, 1-27.

[30] Eristi, S. D., Kurt, A. A., \& Dindar, M. (2012). Teachers' views about effective use of technology in classrooms. Turkish Online Journal of Qualitative Inquiry, 3(2), 30-41.

[31] Eyduran, E., Topal, M., \& Sonmez, A.Y. (2010). Use of factor scores in multiple regression analysis for estimation of body weight by several body measurements in brown trouts (Salmo trutta fario). Int. J. Agric. Biol. 12, 611-615

[32] Fonchamnyo, D.C. (2013). Customers' perception of e-banking adoption in Cameroon: An empirical assessment of an extended TAM. International Journal of Economics and Finance, 5(1), 166176.

[33] Fornell. C., \& Larcker, D.F. (1981). Evaluating structural equation models with unobservable variables and measurement error. Journal of Marketing Research, 18(1), 39-50.

[34] Essah-Hienno, F. (2018, September 4). Workings of the doubletrack system. Retrieved from https://www.graphic.com.gh/features/opinion/workings-of-thedouble-tracksystem.html?fb_comment_id=2357204414294722_235877362747 1134

[35] Gefen, D., Karahanna, E., \& Straub, D. W. (2003). Trust and TAM in online shopping: An integrated model. MIS Quarterly, 27(1), 51-90.

[36] Gupta, S. \& Kim, H.W. (2007). The moderating effect of transaction experience on the decision calculus in on-line repurchase. International Journal of Electronic Commerce, 12(1), 127-158. http://dx.doi.org/10.2753/JEC1086-4415120105

[37] Hair, J.F., William C. B., Barry J. B., \& Rolph E. A. (2010), Multivariate Data Analysis. Englewood Cliffs, NJ: Prentice Hall.

[38] Harfoushi, O., \& Obiedat, R. (20110. E-training acceptance factors in business organizations. IJET 6(2), 15-18.

[39] Hollingsworth, C. L., \& Dembla, P. (2013). Toward an understanding: Why users engage in $\mathrm{m}$-commerce. Proceedings of the Southern Association for Information Systems Conference, Savannah, GA, USA. March 8th-9th 2013.

[40] Hossain, M. M. \& Prybutok, V. R. (2008). Consumer acceptance of RFID technology: An exploratory study. IEEE Transactions on $\begin{array}{lll}\text { Engineering } \quad \text { Management, } & \text { 55(2), }\end{array}$ http://dx.doi.org/10.1109/TEM.2008.919728

[41] Hsia, J., Chang, C., \& Tseng, A. (2014). Effects of individuals' locus of control and computer selfEfficacy on their e-learning acceptance in high-tech companies. Behaviour \& Information Technology, 33(1), 51-64. doi:10.1080/0144929X.2012.702284

[42] Hsu, H. H., \& Chang, Y. Y. (2013). Extended TAM model: Impacts of convenience on acceptance and use of moodle. Online Submission, 3(4), 211-218. 
[43] Ihlebæk, K. A., \& Larsson, A. O. (2018). Learning by doing: Perspectives on social media regulations in Norwegian news organizations. Journalism Studies, 19(6), 905-920. https://doi.org/10.1080/1461670X.2016.1239184

[44] Jadhav, D., Bhutkar, G., \& Mehta, V. (2013). Usability evaluation of messenger applications for education. ALT-J, Research in Learning Technology, 19 (3), 160-169.

[45] Jamieson-Proctor, R., Albion, P., Finger, G., Cavanagh, R., Fitzgerald, R., Bond, T., \& Grimbeek, P. (2013). Development of the TTF TPACK Survey Instrument. Australian Educational Computing, 27(3),26-35.

[46] Johnson, R. B., \& Onwuegbuzie, A. J. (2004). Mixed methods research: A research paradigm whose time has come. Educational Researcher, 33, 14-26.

[47] Kvavik, R. B. (2005). Convenience, communications, and control: How students use technology. Retrieved from https://www.educause.edu/research-and-

publications/books/educating-net-generation/conveniencecommunications-and-control-how-students-use-technology September 15, 2021.

[48] Kaware, S. S., \& Sain, S. K. (2015). ICT Application in Education: An Overview. International Journal of Multidisciplinary Approach \& Studies, 2(1), 25-32.

[49] Kim, H. S., Kim, Y., Chong, K. W., \& Choi, J. (2019). A Study of the Factors Affecting the Intention to Use of Real Estate Crowdfunding. Journal of Information Technology Services, $18(1), 13-26$.

[50] Lai, P.C. (2017a). The literature review of technology adoption models and theories for the novelty technology. Journal of Information Systems and Technology Management, 14(1), 21-38 DOI: $10.4301 / \mathrm{S} 1807-17752017000100002$

[51] Lai, P.C. (2017b). Security as an extension to TAM model: Consumers' intention to use a single platform e-payment. AsiaPacifc J Manag Res Innov., 13,110-119

[52] Lai, P. C., \& Zainal, A. A. (2015). Perceived risk as an extension to TAM model: Consumers' intention to use a single platform epayment. Australia Journal Basic and Applied Science, 9(2), 323330.

[53] Lauricella, S., \& Kay, R. (2013). Exploring the use of text and instant messaging in higher education classrooms. Research in Learning Technology, 21. doi:10.3402/rlt.v21i0.19061

[54] Lee, Y. H., Hsiao, C., \& Purnomo, S. H. (2014).An empirical examination of individual and system characteristics on enhancing e-learning acceptance. Australasian Journal of Educational Technology, 30(5), 561-579.

[55] Levin, T., \& Wadmany, R. (2008). Teachers' views on factors affecting effective integration of information technology in the classroom: Developmental scenery. Journal of Technology and Teacher Education, 16, 233-263.

[56] Li, D., \& Liu, J. (2014). Dynamic capabilities, environmental dynamism, and competitive advantage: Evidence from China. Journal of Business Research, 67(1), 2793-2799.

[57] Li, V. (2017). Social media in English language teaching and learning. International Journal of Learning and Teaching. https://doi.org/10.18178/ijlt.3.2.148- 153

[58] Liaw, S. S. (2008). Investigating students' perceived satisfaction, behavioral intention, and effectiveness of e-learning: A case study of the Blackboard system. Computers \& education, 51(2), 864-873.

[59] Liebana-Cabanillas, F., Sanchez-Fernandez, J., \& Munoz-Leiva, F. (2014). Antecedents of the adoption of the new mobile payment systems: The moderating effect of age. Computers in Human Behavior, 35(0), 464e478.

[60] Lin, W. -S., \& Wang, C. -H. (2012). Antecedences to continued intentions of adopting e-learning systems in blended learning instruction: A contingency framework based on models of information system success and task-technology fit. Computers in Education, 58, 88-99

[61] Lowerison, G., Sclater, J., Schmid, R., \& Abrami, P. (2006). Student perceived effectiveness of computer technology use in post-secondary classrooms. Computers \& Education, 47, 465-489.
[62] Lule, I., (2008). Application of techology acceptance model in mobile banking adoption in Kenya. Nairobi, Kenya: University of Nairobi.

[63] Ma, H., \& Liu, Y. (2005). On Coverage Problems of Directional Sensor Networks. In: Jia X., Wu J., He Y. (eds) Mobile Ad-hoc and Sensor Networks. MSN 2005. Lecture Notes in Computer Science, vol 3794. Springer, Berlin, Heidelberg. https://doi.org/10.1007/11599463_70

[64] Machogu, A. M., \& Okiko, L. (2012). The perception of bank employees towards cost of adoption, risk of innovation, and staff training's influence on the adoption of information and communication technology in the Rwandan commercial banks. Journal of Internet Banking \& Commerce, 17(2), 1-15

[65] Maqableh, M., Masa'deh, R.M.T., Shannak, R.O. \& Nahar, K.M. (2015). Perceived trust and payment methods: An empirical study of MarkaVIP company. Int. J. Communications, Network and $\begin{array}{lllll}\text { System } & \text { Sciences, } & 8, & 409-\end{array}$ http://dx.doi.org/10.4236/ijcns.2015.811038

[66] Marumbwa, J. \& Mutsikiwa, M. (2013). An analysis of the factors influencing consumers' adoption of mobile money transfer services (MMTs) in Masvingo Urban, Zimbabwe. British Journal of Economics, Management and Trade, 3(4), 498-512.

[67] Masinge, K., (2010). Factors influencing the adoption of mobile banking services at the Bottom of the Pyramid in South Africa. Pretoria, South Africa: Gordon Institute of Business Science (GIBS), University of Pretoria.

[68] Mensah, D. K.D. (2019). Teachers' Perspective on Implementation of the Double Track Senior High School System in Ghana. International Journal of Emerging Trends in Social Sciences, 5(2), https://doi.org/https://doi.org/10.20448/2001.52.47.56

[69] Micheni, E. M., Lule, I. \& Muke, G. M. (2013). Transaction costs and facilitating conditions as indicators of the adoption of mobile money services in Kenya. International Journal of Advanced Trends in Computer Science and Engineering (IJATCSE), 9-15

[70] Moghavvemi, S., Sulaiman, A., Jaafar, N. I., \& Kasem, N. (2018). Social media as a complementary learning tool for teaching and learning: The case of youtube. International Journal of Management Education, 16(1), 37-42. https://doi.org/10.1016/j.ijme.2017.12.001

[71] Moyle, K. (2007, September, 21). How can the value of educational technologies in schools be measured?. In C. Montgomerie \& J. Seale (Eds.), Proceedings of ED-MEDIA 2007-World Conference on Educational Multimedia, Hypermedia \& Telecommunications (pp. 130-139). Vancouver, Canada: Association for the Advancement of Computing in Education (AACE). Retrieved from https://www.learntechlib.org/primary/p/25369/.

[72] Mynbayeva, A., \& Sadvakassova, Z. (2018). Pedagogy of the Twenty-First Century: Innovative Teaching Methods Pedagogy of the Twenty-First Century: Innovative Teaching Methods. In New Pedagogical Challenges in the 21st Century - Contributions of Research in Education (pp. 3-20). https://doi.org/10.5772/intechopen.72341

[73] Nakayima, J. K. (2011). Perceived usefulness, perceived ease of use, behavioural intention to use and actual system usage in Centenary Bank (Doctoral dissertation, Makerere,University) http://makir.mak.ac.ug/handle/10570/2607?show=full.

[74] Namaziandost, E. \& Nasri, M. (2019). The impact of social media on EFL learners' speaking skill: A survey study involving EFL teachers and students. Journal of Applied Linguistics and Language Research, 6(3), 199-215.

[75] Nneka, E.H. (2010). The Perspective of e-Learning and libraries in Africa: Challenges and opportunities. Library Review 59 (4), 274290.

[76] Nunnally, J. \& Bernstein, I (1994). Psychometric theory. McGraw Hill, New York

[77] Özbek, A .P. V., Günalan, L. M., Koç, A. P. F., Şahin, N. K., \& Kaş, E. (2015). The effects of perceived risk and cost on technology acceptance: A study on tourists' use of online booking. Celal Bayar Üniversitesi Sosyal Bilimler Dergisi 13(2), 45-55. 
[78] Park, C.K., Kim, H.J., \& Kim, Y.S. (2014). A Study of Factors Enhancing Smart Grid Consumer Engagement. Energy Policy, 72, 211-218.

[79] Park, S. Y, Nam, M., \& Cha, S. (2011). University students' behavioral intention to use mobile learning: Evaluating the technology acceptance model. British Journal of Education Technology, 43(4), 592-605.

[80] Pelham, B.W., \& Blanton, H. (2006). Conducting Research in Psychology: Measuring the Weight of Smoke (3ed). Wadsworth Publishing.

[81] Poushter, J. (2016, February 22). Smartphone ownership and internet usage continues to climb in emerging economies: But advanced economies still have higher rates of technology use. Pew Research Center. Retrieved from http://www.pewglobal. org/2016/02/22/smartphone-ownership-and-internet-usagecontinues-toclimb-in-emerging-economies/.

[82] Purnomo, S. H. \& Lee, Y.H. (2013). E-learning adoption in the banking workplace in Indonesia: An Empirical Study. Information Development 29 (2): 138-153.

[83] Rafique, H., Almagrabi, A. O., Shamim, A., Anwar, F., \& Bashir, A. K. (2020). Investigating the acceptance of mobile library applications with an extended technology acceptance model (TAM). Computers \& Education, 145, 103732.

[84] Rambe, P., Chipunza, C., \& Bere, A. (2013). Towards a novel perspective on the academic use of mobile learning applications: A case of university student perspectives. In D. Nejdet, L. Fuxman, \& F. Victor Lu (Eds.), Globalizing businesses for the next century: visualizing and developing contemporay approaches to harness future opportunities. (pp. 1061-1070). Global Business and Technology Association

[85] Sadi, A. H. M., \& Noordin, M. F. (2011). Factors influencing the adoption of m-commerce: An exploratory analysis. In Proceedings of the 2011 International Conference on Industrial Engineering and Operations Management. Kuala Lumpur, Malaysia.

[86] Setiawan, R., \& Achyar, A. (2012). Effects of Perceived Trust and Perceived Price on Customers' Intention to Buy in Online Store in Indonesia. ASEAN Marketing Journal, 4(1), 26-36.

[87] Shao, Z., Zhang, L., Li, X., \& Guo, Y. (2019). Antecedents of trust and continuance intention in mobile payment platforms: The moderating effect of gender. Electronic Commerce Research and Applications, 33, 100823.

[88] Sharma, S. (1996). Applied multivariate techniques. John Wiley and Sons, Inc., New York

[89] Sobti, N. (2019). Impact of demonetization on diffusion of mobile payment service in India: Antecedents of behavioral intention and adoption using extended UTAUT model. Journal of Advances in Management Research 16(4), 472-497.

[90] Smith, R. (2015, May 21). The Role of Social Media in Higher Education Marketing. Retrieved from http://www.bostoninteractive.com/blog/industries/social-mediahigher-education-marketing

[91] Stone, R.W., \& Eveleth-Baker, L., (2013). Students' expectation, confirmation, and continuance intention to use electronic textbooks. Computer in Human Behavior 29, 984-990.

[92] Suka, M., Yamauchi, T., \& Yanagisawa, H. (2017). Perceived effectiveness rating scales applied to insomnia helpseeking messages for middle-aged Japanese people: a validity and reliability study. Environmental health and preventive medicine, 22(1), 1-8.

[93] Suorsa, J-M. \& Eskilsson, N. (2014). Students' perceptions of learning management systems: An explorative case study of upper secondary school students. Gothenburg, Sweden: Department of Applied Information Technology, University of Gothenburg.
Retrieved

from

https://gupea.ub.gu.se/bitstream/2077/36431/1/gupea_2077_36431 _1.pdf

[94] Susilo, A. (2014, July 18). Exploring Facebook and WhatsApp as supporting social network applications for English learning in higher education. Retrieved from http://simpen.lppm.ut.ac.id/Internasional\%20Seminar/002.\%20Ad hi\%20Susilo_Exploring\%20Facebook\%20and\%20Whatsapp $\% 20$ As\%20Supporting\%20Social\%20Network\%20Applications\%20F or\%20English\%20.pdf

[95] Tang, J. E., Tang, T. I., \& Chiang, C. H. (2012). Blog learning: effects of users' usefulness and efficiency towards continuance intention. Behaviour \& Information Technology, 33(1), 36-50

[96] Tarhini, A., Hone, K., \& Liu, X. (2014). The effects of individual differences on e-learning users' behaviour in developing countries: A structural equation model. Computers in Human Behavior, 41, 153-163. doi:10.1016/j.chb.2014.09.020

[97] Wang, W., Ngai, E. W. T., \& Wei, H. (2011). Explaining Instant Messaging Continuance Intention: The Role of Personality. International Journal of Human-Computer Interaction, 28(8), 500510.

[98] Westera, W. (2015). Reframing the role of educational media technologies. Quarterly Review of Distance Education, 16(2), 1932.

[99] Venkatesh, V., Thong, J. Y. L., \& Xu, X. (2012). Consumer acceptance and use of information technology: Extending the unified theory of acceptance and use of technology. MIS Quarterly, 36(1), 157-178.

[100] Willemse, J. J. (2015). Undergraduate nurses reflections on Whatsapp use in improving primary health care education. Curationis, 38(2), 1-7.

[101] Wu, B., \& Zhang, C. (2014). Empirical study on continuance intentions towards E-learning 2.0 systems. Behaviour \& Information Technology, 33(10), 1027-1038. doi:10.1080/0144929X.2014.934291

[102] Yamane, T. (1973). Statistics - An introductory analysis (3rd ed.) New York: Harper and Row

[103] Yang, S., Lu, Y., Gupta, S., Cao, Y. \& Zhang, R. (2012) Computers in human behavior mobile payment services adoption across time: An empirical study of the effects of behavioral beliefs, social influences, and personal traits. Computers in Human Behavior, 28(1), 129-142, available at: http://doi.org/10.1016/j.chb.2011.08.019

[104] Yeh, R. K. -J. \& Teng, J. T. C. (2011). Extended conceptualization of perceived usefulness. Behaviour \& Information Technology, 31(5), 525-540.

[105] Yoon, C., \& Kim, S. (2007). Convenience and TAM in a ubiquitous computing environment: The case of wireless LAN. Electronic Commerce Research \& Applications, 6(1), 102-112

[106] Zainab, B., Awais Bhatti, M., \& Alshagawi, M. (2017). Factors affecting e-training adoption: an examination of perceived cost, computer self-efficacy and the technology acceptance model. Behaviour \& Information Technology, 36(12), 1261-1273.

[107] Zarmpou, T., Saprkis, V., Markos, A., \& Vlachopoulou, M. (2012). Modeling users' acceptance of mobile services. Electronic Commerce Res, 12, 225-248.

[108] Zarzuela, M. M., Pernas, F. J. D., Calzón, S. M., Ortega, D. G., \& Rodríguez, M. A. (2013). Educational tourism through a virtual reality platform. Procedia Computer Science, 25, 382-388. doi:10.1016/j.procs.2013.11.047

[109] Zhang, D., Xia, F., Yang, Z., Yao, L., \& Zhao, W. (2010). Localization technologies for indoor human tracking. in Proc. FutureTech, 1-6. 